Int. J. Electrochem. Sci., 11 (2016) $8817-8826$

International Journal of

ELECTROCHEMICAL

SCIENCE

www.electrochemsci.org

\title{
Effect of Deposition Time and Temperature on the Performance of Electroless Ni-P Coatings
}

\author{
Shi-Ai Xu ${ }^{1,2, *}$, Chang-Sheng Liang ${ }^{2}$ \\ ${ }^{1}$ School of Chemical Engineering, Qinghai University, Xining 810016, China \\ ${ }^{2}$ School of Materials Science and Engineering, East China University of Science and Technology, \\ Shanghai 200237, China \\ *E-mail: saxu@ecust.edu.cn
}

doi: $10.20964 / 2016.10 .55$

Received: 3 June 2016 / Accepted: 21 August 2016 / Published: 6 September 2016

In this study, electroless nickel-phosphorous (Ni-P) coatings were deposited on the copper $(\mathrm{Cu})$ substrate in order to improve the electrolyte resistance of electrode tabs of lithium ion battery. The effects of treatment time and temperature on the surface morphology, composition and corrosion resistance of the deposited copper were investigated by scanning electron microscopy (SEM), energy diffraction spectroscopy (EDS), X-ray photoelectron spectroscopy (XPS), electrochemical impedance spectroscopy (EIS) and electrolyte immersion test. The results show that Ni-P coatings deposited at 75 $-80{ }^{\circ} \mathrm{C}$ for more than $10 \mathrm{~min}$ have much smoother surfaces, and Ni-P coating deposited at $75{ }^{\circ} \mathrm{C}$ for $25 \mathrm{~min}$ has the best corrosion resistance. All Ni-P coatings have good electrolyte resistance and can endure the electrolyte at $80{ }^{\circ} \mathrm{C}$ for at least $48 \mathrm{~h}$.

Keywords: lithium ion battery; nickel-plated copper tab; corrosion resistance; electrolyte resistance

\section{$\underline{\text { FULL TEXT }}$}

(C) 2016 The Authors. Published by ESG (www.electrochemsci.org). This article is an open access article distributed under the terms and conditions of the Creative Commons Attribution license (http://creativecommons.org/licenses/by/4.0/). 